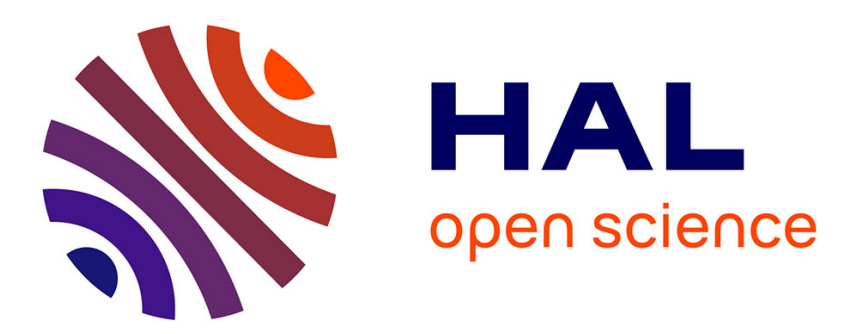

\title{
Seasonal changes in plasma levels of steroid hormones in an asynchronous fish the gudgeon Gobio gobio L. (Teleostei;Cyprinidae)
}

\author{
J. Rinchard, Patrick Kestemont, E.R. Kühn, Alexis Fostier
}

\section{- To cite this version:}

J. Rinchard, Patrick Kestemont, E.R. Kühn, Alexis Fostier. Seasonal changes in plasma levels of steroid hormones in an asynchronous fish the gudgeon Gobio gobio L. (Teleostei;Cyprinidae). General and Comparative Endocrinology, 1993, 92, pp.168-178. 10.1006/gcen.1993.1153 . hal-02715626

\section{HAL Id: hal-02715626 \\ https://hal.inrae.fr/hal-02715626}

Submitted on 1 Jun 2020

HAL is a multi-disciplinary open access archive for the deposit and dissemination of scientific research documents, whether they are published or not. The documents may come from teaching and research institutions in France or abroad, or from public or private research centers.
L'archive ouverte pluridisciplinaire HAL, est destinée au dépôt et à la diffusion de documents scientifiques de niveau recherche, publiés ou non, émanant des établissements d'enseignement et de recherche français ou étrangers, des laboratoires publics ou privés. 


\title{
Seasonal Changes in Plasma Levels of Steroid Hormones in an Asynchronous Fish the Gudgeon Gobio gobio L. (Teleostei, Cyprinidae)
}

\author{
J. Rinchard,${ }^{*}$ P. Kestemont,${ }^{*}$ E. R. Kühn, $\dagger$ And A. Fostier $\ddagger$ \\ * Unité d'Ecologie des Eaux Douces, Facultés Universitaires Notre-Dame de la Paix, rue de Bruxelles, 61, \\ B-5000 Namur, Belgique; tLaboratorium voor vergelijkende Endocrinologie, Katholiek Universiteit van \\ Leuven, Naamsestraat, 6I, B-3000 Leuven, Belgique; and $¥$ Laboratoire de Physiologie des Poissons, INRA, \\ Campus de Beaulieu, 35042 Rennes, Cédex, France
}

Accepted June 24, 1993

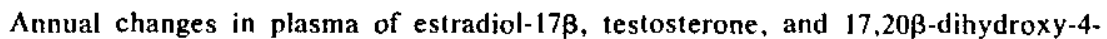
pregnen-3-one concentrations were measured, by radioimmunoassay, in female gudgeon Gobio gobio a fish which has an asynchronous-type ovary containing oocytes at various stages of development and spawns several times during the reproductive period. The gonadosomatic index and the relation between stages of maturity and steroid concentrations were also followed during the reproductive cycle. Plasma levels of estradiol-17\%, testosterone, and 17,20 3 -dihydroxy-4-pregnen-3-one were low from October to April and increased rapidly in May to reach $0.61 \pm 0.31 ; 2.3 \pm 0.42$; and $3.17 \pm 0.68 \mathrm{ng} / \mathrm{ml}$, respectively. Elevated levels were maintained during spawning when vitellogenic oocytes are present alongside oocytes in final maturation. Histological analysis of the ovary indicated that an important number of spawnings has occurred since the proportion of oocytes in final maturation stage was very low (less than 1\%). Fish in the regressive phase also presented high steroid levels. The vitellogenic oocytes in preovulatory atresia and the postovulatory follicles may be responsible for these events. O 1993 Academic Press, inc.
\end{abstract}

Seasonal and annual changes in the plasma steroid levels of teleost fish have been extensively investigated (Scott et al., 1980, 1983; Breton et al., 1983; Fostier et al., 1983; Kagawa et al., 1983; Kadmon et al., 1985; Fostier and Jalabert, 1986; Kobayashi et al., 1986; Pankhurst and Conroy, 1987; Rosenblum et al., 1987; Galas and Bieniarz, 1989; Kobayashi et al., 1989; Berlinsky and Specker, 1991; Matsuyama et al., 1991: 'Tamaru et al., 1991). These studies were carried out mostly on species which present a synchronous or a groupsynchronous oocyte development and spawned only once per year or once during their life. Fish with asynchronous oocyte development have received little attention. This type of oocyte development implies that during reproductive period, ovary contains oocytes at all stages of development and since yolky oocytes still remain in the ovary after ovulation, these species are able to spawn several times during a spawning period.

The purpose of the present study was to follow seasonal changes in the serum concentrations of several gonadal steroids in the gudgeon Gobio gobio, one of the cyprinid fish, which spawns several times during the reproductive season. Correlations between these changes and the stages of gonadal development were also examined.

\section{MATERIALS AND METHODS}

The study was conducted between October, 1990 and July, 1991. In October, an outdoor pond (area: $112 \mathrm{~m}^{2}$, maximum depth:90 cm) was stocked with 504 gudgeons and maintained under these seminatural conditions until the end of the experiment. Fish were sampled by electrofishing during the whole reproductive cycle at 11:00 AM. 


\section{Sampling Procedures}

The fish were anesthetized with ethylene glycol monophenyl ether $\left(2-5 \mathrm{ml} / 10\right.$ liter $\mathrm{H}_{2} \mathrm{O}$ ). Total body length $( \pm 0.1 \mathrm{~cm})$ and weight $( \pm 0.1 \mathrm{~g})$ were measured. Blood samples were taken from the caudal vessel into a heparinized syringe, centrifuged for $15 \mathrm{~min}$ at $10,000 \mathrm{~g}$, and the plasma was stored at $-20^{\circ}$ until radioimmunoassay. The ovaries were removed, weighed $( \pm 0.001 \mathrm{~g})$, and fixed in Bouin's solution for histological examination. Tissues embedded in paraffin were prepared into $6-\mu \mathrm{m}$ sections and stained with trichrome:hemaluin, phloxine, and light green (Langeron, 1942).

\section{Morphological Parameter}

Gonadosomatic index $(\mathrm{GSI})=100 \times W_{\mathrm{o}} / W_{\mathrm{f}}$, where $W_{\mathrm{f}}=$ weight of the entire fish $(\mathrm{g})$, and $W_{\mathrm{o}}=$ weight of the ovary $(\mathrm{g})$.

\section{Radioimmunoassay}

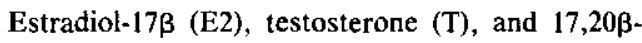
dihydroxy-4-pregnen-3-one $(17,20 \beta \mathrm{P})$ were measured by radioimmunoassay (Gamma Master Counter 1277 for E2 and T and Miniaxi Tricarb 4000 Series United Technologies Packard for 17,20ßP) in plasma following cyclohexane/ethyl acetate (v/v) extraction. Samples of 50 or $75 \mu \mathrm{l}$ of plasma were extracted with 800 or $1200 \mu \mathrm{l}$ cyclohexane/ethyl acetate, respectively, dried down, and redissolved in $40 \mu \mathrm{l} 0.01$ phosphate buffer.

Test kits for the direct radioimmunological determination of E2 and T were purchased from Mallinckrodt Laboratories Diagnostica (France) and Biotecx Laboratories Inc. (U.S.A.), respectively. Dilution of plasma showed parallelism with standard curves for these hormones. Testosterone was assayed in extracted samples using the procedure described by Lamba et al. (1982). A sensitivity of $0.312 \mathrm{ng} / \mathrm{ml}$ was obtained and the inter- and intraassay coefficients of variation were 11.5 and $6.0 \%$, respectively.

Plasma concentrations of $17,20 \beta$ P were measured according to the methods of Fostier et al. (1981). Cross-reactivities of various steroids with the antisera used in the radioimmunoassays have been described (Fostier and Jalabert, 1986).

\section{Histological Analysis}

Each gonad was classified according to the most advanced type of oocyte present (Table 1). Kestemont (1987) showed that one section of gonad and one field per section are representative of the whole ovary. Ovary development was examined by a histomorphometric approach similar to that described by Kestemont (1987). Two parameters were examined: (1) dis- tribution of oocyte size, evaluated by measuring 50 profiles for stage 1 to 3 or 25 profiles for stage 4 to 8 ; (2) relative proportion of each stage, i.e., counting 300 cells per ovary and then dividing the percentage of a defined stage by the corresponding oocyte mean diameter.

\section{Data Analysis}

All data are expressed as the mean \pm SEM. Data were statistically analyzed by an analysis of variance (ANOVA 1) followed by comparison of means using Scheffe $F$ 's test. A Hartley test was carried out to verify the homogeneity of variance. The data of E2 were log-transformed before statistical analysis.

\section{RESULTS}

Seasonal changes in pond temperature and daylength during the study period are shown in Fig. 1. Pond temperature varied from a minimum value of $2^{\circ}$ during February to a maximum of $19^{\circ}$ in summer. During January a layer of ice formed on the pond. Daylength was longest in July (16 hr/30 min) and shortest $(8 \mathrm{hr} / 30 \mathrm{~min})$ in December.

\section{Gonadosomatic Index (Fig. I)}

From October to March the gonadosomatic index of $G$. gobio increased slowly from $3.10 \pm 0.17 \%$ to $4.59 \pm 0.26 \%$ and then rapidly to reach a peak in May-June $(16.53 \pm 1.53 \%)$. In mid-June, the GSI decreased greatly, indicating the onset of the gonadal regression.

\section{Plasma Sex Steroid Levels}

Profiles of plasma levels of E2, T, and $17,20 \beta \mathrm{P}$ in females are shown in Fig. 2.

Plasma E2 levels were low $(<0.16 \mathrm{ng} / \mathrm{ml})$ from October to April and rapidly increased to $0.61 \pm 0.36 \mathrm{ng} / \mathrm{ml}$ in early May. Levels then declined to $0.19 \pm 0.05 \mathrm{ng} / \mathrm{ml}$ in late May but in June, there was a new peak of E2 $(1.60 \pm 0.35 \mathrm{ng} / \mathrm{ml})$.

Plasma $\mathrm{T}$ levels were low from October to April but during the reproductive period, three peaks were observed, reaching $1.63 \pm$ 
TABLE 1

The Maturity Stages of the Ovary of the Gudgeon Gobio gobio

$\begin{array}{ccc}\text { Ovarian stage } & \begin{array}{c}\text { Oocyte stages present } \\ \text { in the ovary }\end{array} & \begin{array}{c}\text { Description of the } \\ \text { most advanced oocytes }\end{array}\end{array}$

(1) Immature

(2) Onset of endogenous vitellogenesis

(3) Complete of endogenous vitellogenesis

(4) Onset of exogenous vitellogenesis

(5) Progress of exogenous vitellogenesis

(6) Complete of exogenous vitellogenesis

(7) Onset of final maturation

(8) Progress of final maturation

(9) Preparation to a new spawning

(10) Postspawning
Previtellogenic oocytes

Previtellogenic oocytes and oocytes in endogenous vitellogenesis

Previtellogenic oocytes and oocytes at different stages of endogenous vitellogenesis

Previtellogenic oocytes, oocytes at different stages of endogenous vitellogenesis, and oocytes in exogenous vitellogenesis

Previtellogenic oocytes and oocytes at different stages of endogenous and exogenous vitellogenesis

Previtellogenic oocytes and oocytes at different stages of endogenous and exogenous vitellogenesis

Previtellogenic oocytes, oocytes at different stages of endogenous and exogenous vitellogenesis, and oocytes in final maturation

Previtellogenic oocytes, oocytes at different stages of endogenous and exogenous vitellogenesis, and oocytes in final maturation

Previtellogenic oocytes, oocytes at different stages of endogenous and exogenous vitellogenesis, and postovulatory follicles

Previtellogenic oocytes and pre- and postovulatory follicles
Oocytes with vacuole free cytoplasm (without yolk substance) (previtellogenesis)

Oocytes at primary yolk vesicle stage, glycoprotein appear and occupy two or three rings in the cytoplasm periphery (early endogenous vitellogenesis)

Oocytes are full of glycoprotein inclusions. Follicular and cellular layers are differentiated (late endogenous vitellogenesis)

Oocytes at primary yolk globule stage with small lipoprotein inclusions in periphery of the cytoplasm (early exogenous vitellogenesis)

Oocytes are full of yolk globules and the yolk vesicles are in periphery of the cytoplasm (progress exogenous vitellogenesis)

Appearance of the micropyle in yolk oocytes (late exogenous vitellogenesis)

Migration of the germinal vesicle (G.V.) to the micropyle (mig. G.V.)

Germinal vesicle couple with the micropyle (G.V. couple)

The follicle cells in the postovulatory follicles, hypertrophy and multiply, showing phagocytosis

The granulosa cells of preovulatory follicles hypertrophy and the yolk substance degenerates 


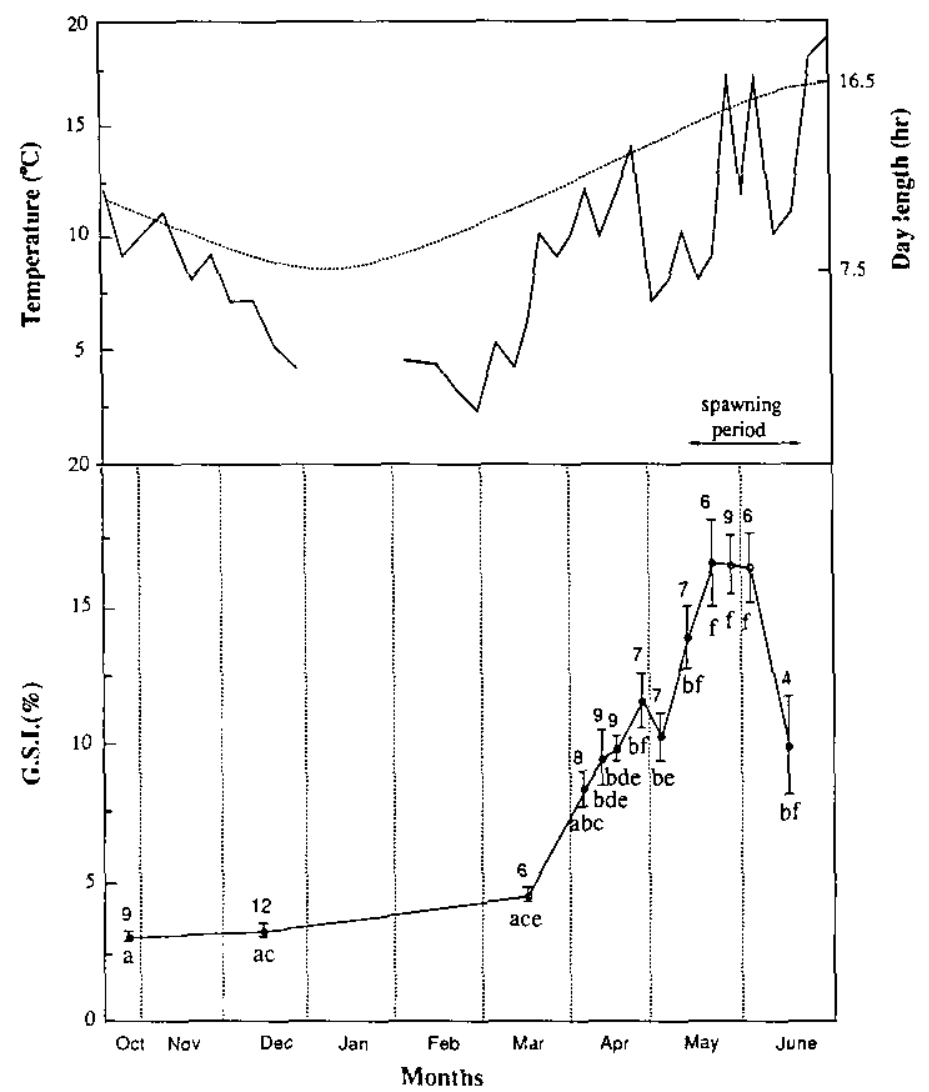

FIG. 1. Seasonal changes in the gonadosomatic index (GSI) of female gudgeon $G$. gobio with changes in water temperature (-) and daylength (-..). Each value represents the mean \pm SEM. The numbers above the data points indicate the number of fish sampled. The data points showing the same letter are not significantly different $(P<0.05)$.

$0.38 ; 2.30 \pm 0.42 ; 1.86 \pm 0.69 \mathrm{ng} / \mathrm{ml}$, respectively.

Plasma 17,20ßP levels increased significantly in May to peak at $2.81 \pm 0.49 \mathrm{ng} / \mathrm{ml}$ and then fall to $2.04 \pm 0.53 \mathrm{ng} / \mathrm{ml}$ in early June. A significant amount of 17,20 $\beta \mathrm{P}$ was found in the last sample $(2.46 \pm 0.51 \mathrm{ng} / \mathrm{ml})$. Although these peaks are not statistically significant, probably because of a lack of synchrony between individuals, they do indicate a cyclic pattern of changes in these batch spawners.

\section{Histological Analysis}

Based on histology, spawning first took place in early May. Indeed, at this time, ovary presented oocytes in late exogenous vitellogenesis (stage 6) with micropyle (stage 7). In the last sample, some fish always presented these types of oocytes and had probably not completed their spawning season.

To understand oocyte growth in an asynchronous ovary, the fact that oogenesis is a continuous process must be taken into account. At a given stage, the growth of oocytes increases the mean size of that stage, but growth of the largest oocytes into the next stage (e.g., by inclusion of yolk vesicles or yolk globules) or the entry of small oocytes from the lower stage produces a decrease in the mean diameter of this stage (Kestemont, 1987). 


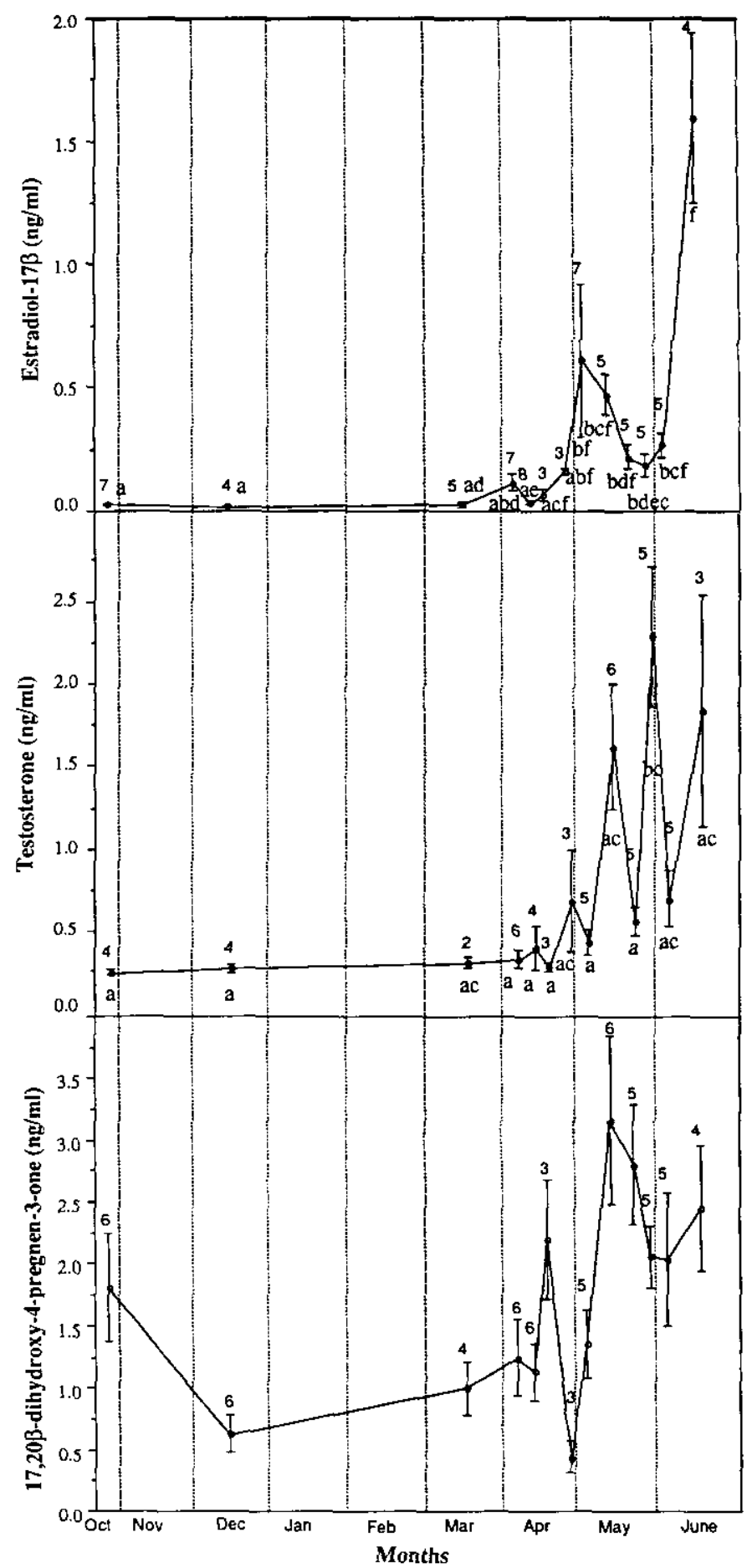

FIG. 2. Annual changes in steroid hormone levels in female gudgeon. Each value represents the mean \pm SEM. The numbers above the data points indicate the number of fish sampled. The data points showing the same letter are not significantly different $(P<0.05)$. No significant differences are found for $17,20 \beta$-dihydroxy-4-pregnen3-one. 
The change in mean percentages of different oocyte stages and in mean size (diameter) of oocyte are shown in Figs. 3 and 4 , respectively.

From October to March, only stages 1, 2, and 3 were present in each sample in percentages of 66.5 to $85 \%, 6.5$ to $19 \%$, and 2 to $6.5 \%$, respectively.

In April, with the onset of exogenous vitellogenesis, the diameter of the oocytes increased (up to $772 \mu \mathrm{m}$ at the end of exogenous vitellogenesis). Enlargement of the oocytes by accumulation of yolk globules caused a marked increase in GSI.

In May and June, oocyte maturation occurred. However, the percentages of ovary presented oocytes in maturation are as follows: stages 6,7 , and 8 were very low, 0.4 , 0.1 , and $0.06 \%$, respectively. The mean diameter of the most advanced oocyte increased and reached $840 \mu \mathrm{m}$ for stage 6,878 $\mu \mathrm{m}$ for stage 7 , and $917 \mu \mathrm{m}$ for stage 8 . If these three stages are grouped, less than $1 \%$ of oocytes was laid in each spawning.

For individual fish, there was no relation either between $\mathrm{E} 2$ levels and the proportion of oocytes in exogenous vitellogenesis (stages 4 and 5) or between 17,20 $\mathrm{\beta P}$ levels and the proportion of oocytes in final maturation (stages 6, 7, and 8).

\section{Plasma Hormone Levels in Relation to Oocyte Stages}

Changes in plasma E2, T, and 17,20 $\mathrm{P}$ levels at various oocyte stages are shown in Fig. 5 .

The level of E2 was low during endogenous vitellogenesis, increased significantly at the beginning of the yolk accumulation, and remained at high levels during exogenous vitellogenesis. In stage 8 , just before germinal vesicle breakdown, the level of E2 decreased. In stage 9 , containing both oocytes in complete vitellogenesis and postovulatory follicles, the levels of E2 were very high $(0.61 \pm 0.32 \mathrm{ng} / \mathrm{ml})$. Concentrations remained high in stage 10 , with the ovary entering the regressive phase $(0.61 \pm 0.33 \mathrm{ng} / \mathrm{ml})$. In these stages, there were large individual variations.

The level of $\mathrm{T}$ was low during the endog-

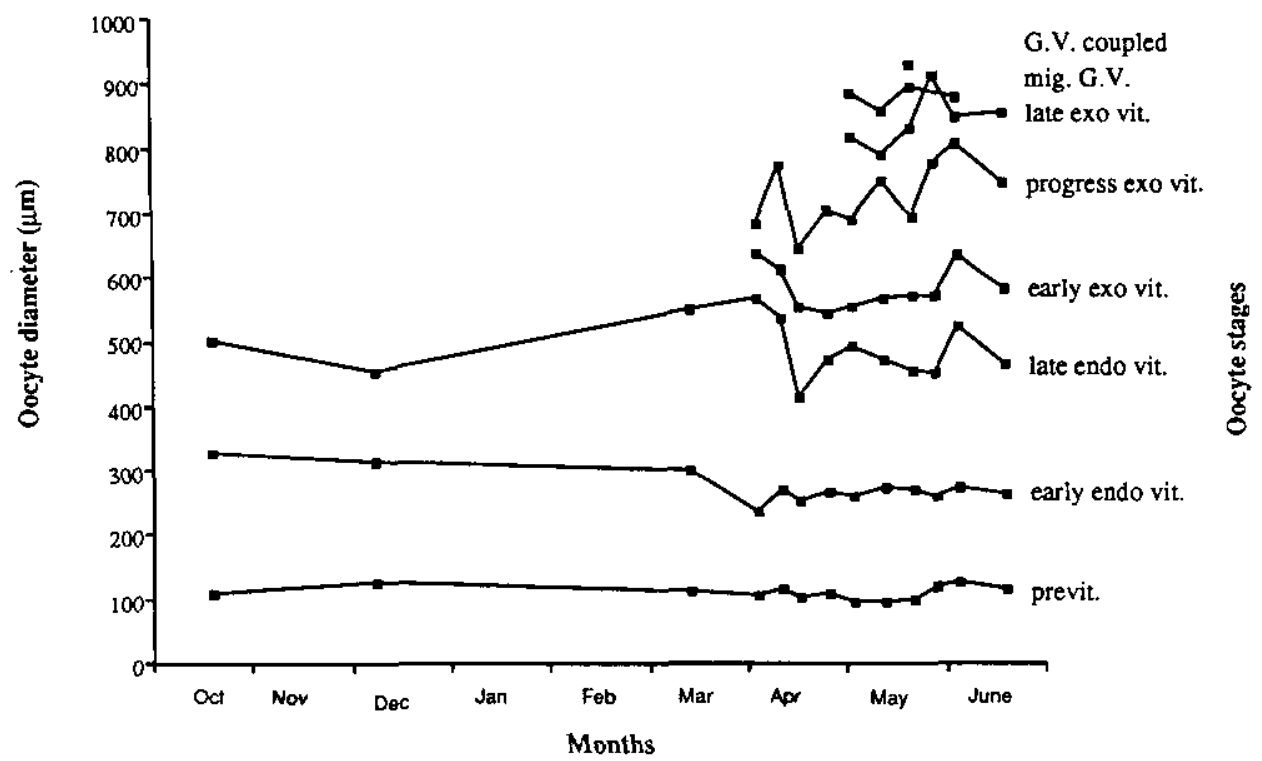

FIG. 3. Annual changes of mean diameter of oocyte stages in female gudgeon (see Table 1 for the descriptions of oocyte stages). 


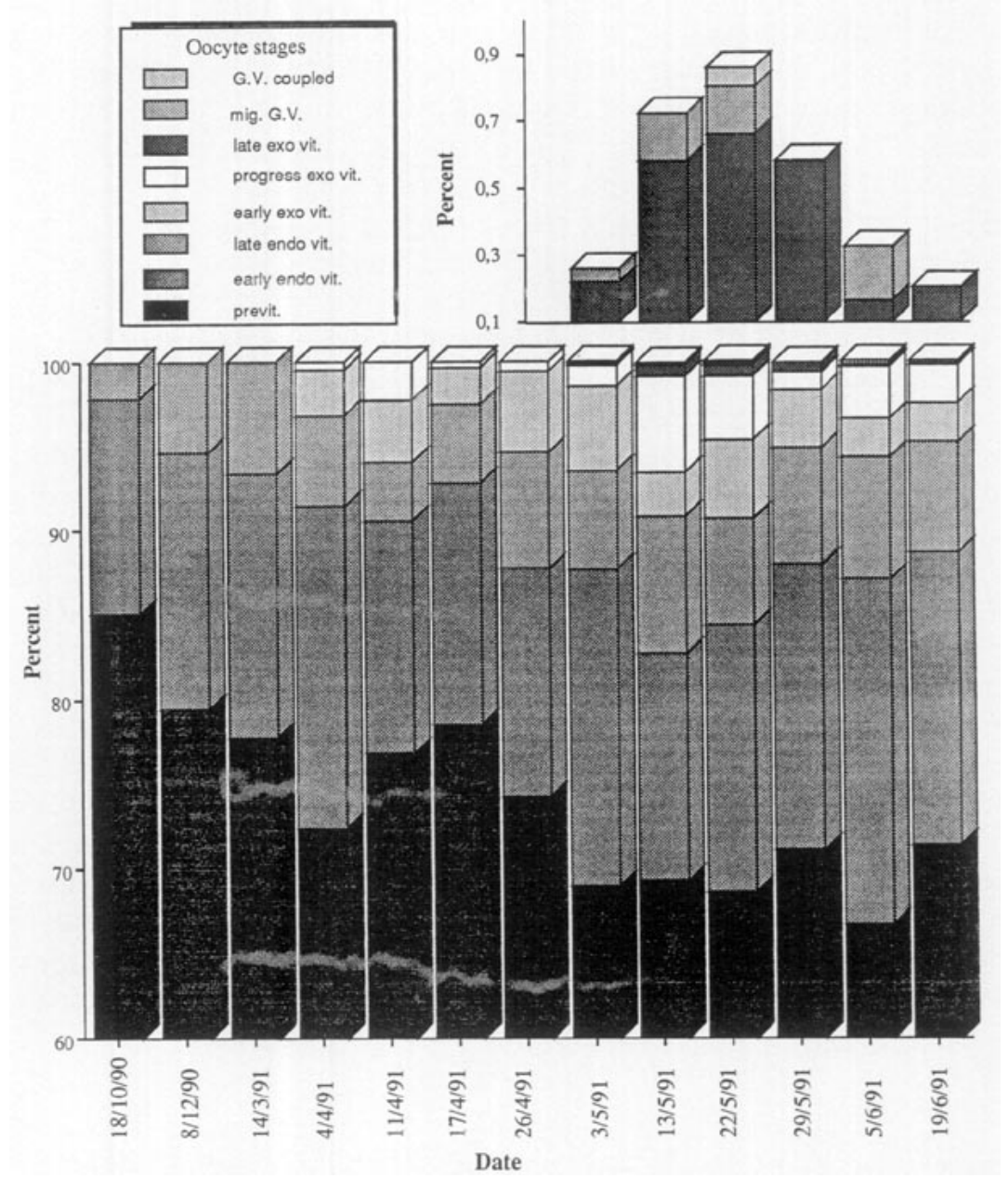

Fig. 4. The percentages of the different oocyte stages in female gudgeon during the sexual cycle (see Table 1 for the descriptions of oocyte stages).

enous vitellogenesis and the beginning of the exogenous vitellogenesis. It increased at the end of exogenous vitellogenesis (stage 6). Just before ovulation (stage 8) the concentration of T decreased to $0.42 \mathrm{ng} / \mathrm{ml}$. As with $\mathrm{E} 2$, the levels of $\mathrm{T}$ were high during stages 9 and 10 at $1.32 \pm 0.63$ and $0.94 \pm$ $0.28 \mathrm{ng} / \mathrm{ml}$, respectively.

The levels of $17,20 \beta \mathrm{P}$ were low during vitellogenesis but in the late exogenous vitellogenesis the levels increased to $2.87 \pm$ $0.30 \mathrm{ng} / \mathrm{ml}$ and remained high during the final maturation. In stages 9 and 10 , the concentrations of this steroid as for the other steroids remained high.

\section{DISCUSSION}

The occurrence of seasonally phased reproduction in gudgeon with spawning occurring in spring, is consistent with earlier observations made over several years (Kestemont, 1987, 1988, 1990). This small fish, presenting an asynchronous oocyte development as defined by Wallace and Selman (1981), can ovulate several batches of eggs within a single reproductive season. The hypothesis that gudgeon females ovulated at least four times during the reproductive season with a 7- or 15-day interval between two successive spawnings was suggested 

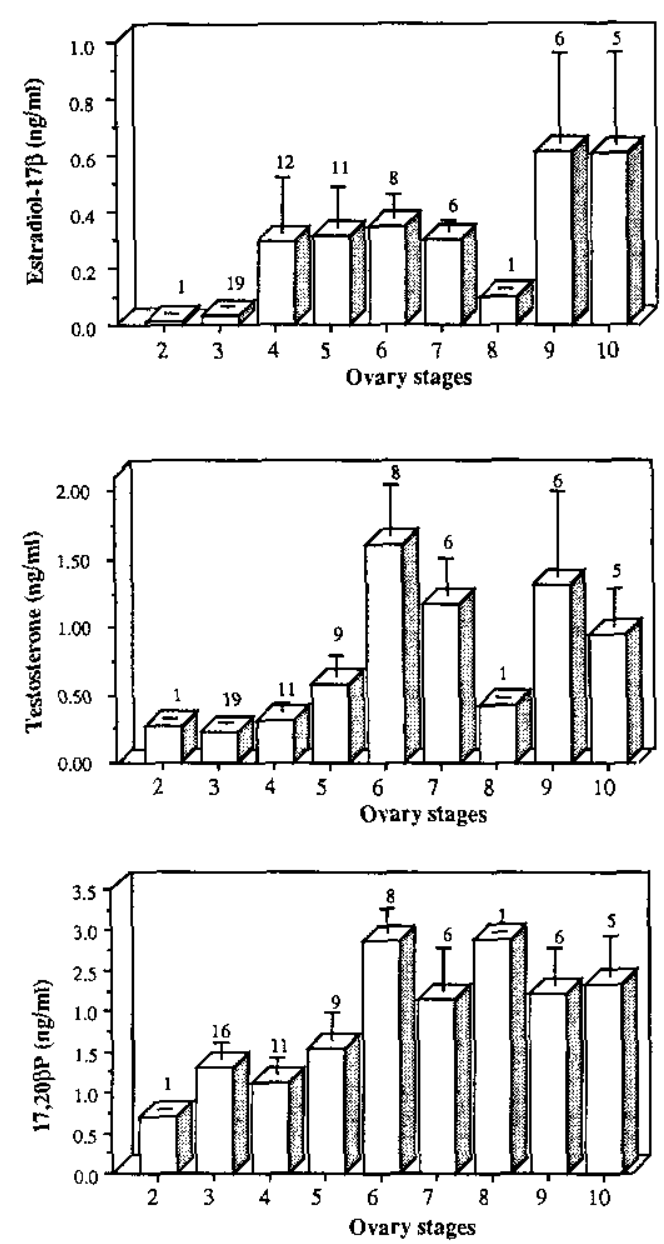

Fig. 5. Comparison of levels of steroid hormones in female gudgeon during ovarian development. Each value represents the mean \pm SEM. The numbers above the data points indicate the number of fish sampled.

by Penaz and Prokes (1978) who studied the ontogenesis in gudgeon. In this study, it is not possible to determine the periodicity of spawning and the number of eggs released during a spawning event. However, histological analysis of ovary indicates that an important number of spawnings have taken place since the proportion of oocytes in final maturation stage was very low (less than $1 \%$ ) during the spawning season.

This study describes for the first time the changes in plasma steroid hormones $(\mathrm{E} 2, \mathrm{~T}$, $17,20 \beta P$ ) during the annual reproductive cycle of the gudgeon. Oocyte development is relatively slow from October to March and the ovaries contained only previtellogenic and different stages of endogenous vitellogenesis oocytes. During this period, blood concentration of estrogen and androgen are both low, associated with a low GSI. This is in agreement with findings in other teleosts (Pankhurst and Conroy, 1987; Berlinsky and Specker, 1991). The level of serum E2 began to increase in April coincident with the appearance of yolk globule in the oocytes. This is consistent with the role of estrogen in promoting hepatic synthesis of the yolk precursor. As observed in other species (Kagawa et al., 1983; Breton et al., 1983; Galas and Bieniarz, 1989), the females have an increased GSI and oocyte diameter (mean diameter of oocytes in exogenous vitellogenesis: 726 $\mu \mathrm{m})$ correlated with increase of E2. The highest level of E2 was observed during the spawning period (May-June). Similar patterns have also been observed in other multiple spawning fishes as Carassius auratus (Kagawa et al., 1983), Sparus aurata (Kadmon et al., 1985), and Dicentrarchus labrax (Prat et al., 1990). These teleosts have an asynchronous ovarian development and after ovulation, their ovaries contain both protoplasmic oocytes and oocytes at various stages of vitellogenesis; these remaining vitellogenic oocytes were able to produce this steroid after ovulation (Kagawa $e t$ al., 1984).

Although a significant increase of E2 occurred during the season of reproduction, the absolute level of this steroid was low. Low absolute levels of plasma E2 also occur among species with either asynchronous (Pankhurst and Conroy, 1987) or synchronous ovarian development (Pankhurst and Conroy, 1988) except in salmonid, which may be as high as $50 \mathrm{ng} / \mathrm{ml}$ (Scott and Sumpter, 1983). It is clear that the large interspecific differences in absolute levels of plasma E2 that occur in teleosts during recrudescence are not a function of mode of 
ovarian development (Pankhurst and Conroy, 1988). On the other hand, Berlinsky and Specker (1991) suggested that low levels of steroids may be due in part to differences in sampling procedure. Indeed, stress of capture can have profound effects upon the endocrine profiles of teleosts. But it is not known how long it takes for the effects of stress to be observed in terms of changes in plasma levels of gonadal steroids (Pankhurst and Conroy, 1988).

Testosterone has been reported in the blood of a number of female teleosts but the precise role of this steroid is unclear. $T$ as a precursor for E2 synthesis is released into the plasma when no longer needed for aromatization. Fostier et al. (1983) suggested that at high concentrations $\mathrm{T}$ may have vitellogenic actions on the liver. Plasma $T$ levels increase at the end of vitellogenesis. This acute rise in $\mathrm{T}$ indicates that oocytes are fully mature in the ovary and ready to ovulate (Kobayashi et al., 1987). The functional significance of the increased $\mathrm{T}$ remains unknown. However, Nagler and Idler (1992) suggest a role for $T$ during the final maturation-ovulation process in winter flounder, as highest levels of $T$ occurred during the prespawning and spawning periods. After ovulation, high levels are maintained since the ovary contains oocytes at different stages of maturity.

$17,20 \beta \mathrm{P}$ is one of the most potent steroids for inducing final oocyte maturation and high levels have been found in the plasma of mature species (Nagahama, 1987; Nagahama and Yamoshita, 1989). Since the gudgeon displays asynchronous oocyte development, high levels of plasma E2 and $17,20 \beta \mathrm{P}$ were maintained during the spawning season, as vitellogenic oocytes coexist with oocytes in final maturation. However, in the present study, E2 and the absolute concentration of $17,20 \beta \mathrm{P}$ observed are very low compared with those in salmonid fish. In these species, final maturation and ovulation occurred for all oocytes simultaneously and high $17,20 \beta \mathrm{P}$ levels mediated this event. In asynchronous fish, only a small proportion of the follicles will be producing maturational steroids at any time. In gudgeon, the proportion of oocytes in final maturation stage was very low: $0.4 \%$ for stage $6,0.1 \%$ for stage 2 , and $0.06 \%$ for stage 8. As reported in C. auratus (Kagawa et al., 1983), the follicle may appear to have a lower capacity to produce this steroid compared to the follicles of rainbow trout Oncorhynchus mykiss (Fostier et al., 1981). On the other hand, 17,20ßP would be rapidly metabolized and present only for a brief period and rapidly deactivated (Kime, 1990). A peak is unlikely to be found during weekly sampling unless it coincides closely with spawning. In goldfish (Kobayashi $e t$ al., 1987), low levels of plasma 17,20ßP were due to short-term secretion and/or rapid plasma clearance of this steroid. Another suggestion to explain low levels of $17,20 \beta \mathrm{P}$ is that this progestagen is not the maturation induction steroid (MIS). In fact, as was previously indicated in some other species (Prat et al., 1990), no measurable change in plasma levels of $17,20 \beta \mathrm{P}$ was found during the spawning period of gudgeon. In vitro experiments using gudgeon ovarian tissue are required to determine the potency of this or other steroids in oocyte final maturation.

During the postspawning, high levels of all steroids measured are found. At this time, the ovaries contain protoplasmic oocytes, postovulatory follicles, and many vitellogenic oocytes in preovulatory atresia. When yolky oocytes become atretic, the granulosa cells hypertrophy and serve a phagocytic function. In addition to the removal of atretic oocytes, the follicular cells are involved in the steroidogenesis. In goldfish, Khoo (1975) observed that the steroidogenic function is apparent only after complete removal of atretic oocytes and in the postovulatory follicles steroidogenesis is immediate after ovulation. In this species, in vitro experiments showed that postvitellogenic follicles pro- 
duced T but not E2 (Kobayashi et al., 1989). The high levels of $\mathrm{E} 2$ found in gudgeon during the gonadal regression are probably produced by preovulatory atretic follicles. Kagawa et al. (1983) suggested that the postovulatory follicle of goldfish produces $17,20 \beta \mathrm{P}$ some 6 to $10 \mathrm{hr}$ after ovulation. In Oncorhynchus rhodurus this steroidogenic activity of the postovulatory follicles remains for 1 to 3 days after ovulation (Young et al., 1983).

\section{ACKNOWLEDGMENTS}

We express our gratitude to Professor J. C. Micha (UNECED, FUNDP, Belgium) for supervising this work. We thank Professor R. Leloup (Department of Histology and Embryology, FUNDP, Belgium) for access to his laboratory and Dr. A. Biamungu (KUL, Belgium) for help in measuring estradiol-17 $\beta$ and testosterone concentrations.

\section{REFERENCES}

Berlinsky, D. L., and Specker, J. L. (1991). Changes in gonadal hormones during oocyte development in the striped bass, Morone saxatilis. Fish Phys. Biochem. 9, 51-62.

Breton, B., Fostier, A., Zohar, Y., Lebail, P. Y., and Billard, R. (1983). Gonadotropine glycoprotéque et estradiol-17 $\beta$ pendant le cycle reproducteur chez la truite fario (Salmo trutta) femelle. Gen. Comp. Endocrinol. 49, 220-231.

Fostier, A., Breton, B., Jalabert, B., and Marcuzzi, O. (1981). Evolution des niveaux plasmatiques de la gonadotropine glycoprotéique et de la $17 \alpha$ hydroxy-20ß-dihydroprogesterone au cours de la maturation et de l'ovulation chez la truite arc-enciel, Salmo gairneri. C.R. Hebd. Séances Acad. Sci. 293, 817-820.

Fostier, A., Jalabert, B., Billard, R., Breton, B., and Zohar, Y. (1983). The gonadal steroids. In "Fish Physiology" (W. S. Hoar, D. J. Randall, and E. M. Donaldson, Eds.), Vol. 11A, pp. 277-372. Academic Press, New York.

Fostier, A., and Jalabert, B. (1986). Steroidogenesis in rainbow trout (Salmo gairneri) at various preovulatory stages: Changes in plasma hormone levels and in vivo and in vitro responses of the ovary to salmon gonadotropin. Fish Physiol. Biochem. 2, $87-99$.

Galas, J., and Bieniarz, K. (1989). Seasonal changes of sex steroids in mature and male carp, (Cyprinus carpio L.). Pol. Arch. Hydrobiol. 36, 407-416.

Kadmon, G., Yaron, Z., and Gordin, H. (1985). Se- quence of gonadal events and estradiol levels in Sparus aurata (L.) under two photoperiod regimes. J. Fish Biol. 26, 609-620.

Kagawa, H., Young, G., and Nagahama, Y. (1983). Changes in plasma steroid hormone levels during gonadal maturation in female goldfish (Carassius auratus). Bull. Jpn. Soc. Sci. Fish. 49, 1783-1787.

Kagawa, H., Young, G., and Nagahama, Y. (1984). In vitro estradiol- $17 \beta$ and testosterone production by ovarian follicles of the goldfish. Carassius auratus. Gen. Comp. Endocrinol. 54, 139-143.

Kestemont, P. (1987). Etude du cycle reproducteur du goujon, Gobio gobio L. 1. Variations saisonnières dans l'histologie de l'ovaire. J. Appl. Ichthyol. 4, 145-157.

Kestemont, P. (1988). Etude des potentialités d'élevage intensif du goujon, Gobio gobio, L. Reproduction et croissance larvaire. Dissertation présentée en vue de l'obtention du grade de Docteur en Sciences, Facultés Universitaires Notre-Dame de la paix, Namur (Inédit).

Kestemont, P. (1990). Dynamic aspects of ovogenesis in an asynchronous fish, the gudgeon Gobio gobio L. (Teleostei, Cyprinidae), under controlled temperature and photoperiod conditions. Aquat. Living Resour. 3, 61-74.

Khoo, K. H. (1975). The corpus luteum of goldfish (Carassius auratus L.) and its functions. Can.J. Zool. 53, 1306-1323.

Kime, D. E. (1990). In vitro metabolism of progesterone, 17-hydroxyprogesterone, and 17,20 3 dihydroxy-4-pregnen-3-one by ovaries of the common carp Cyprinus carpio: Production rates of polar metabolites. Gen. Comp. Endocrinol. 79, 406414.

Kobayashi, M., Aida, K., and Hanyu, I. (1986). Annual changes in plasma levels of gonadotropin and steroid hormones in goldfish. Bull. Jpn. Soc. Sci. Fish. 52, 1153-1158.

Kobayashi, M., Aida, K., and Hanyu, I. (1987). Hormone changes during ovulation and effects of steroid hormones on plasma gonadotropin levels and ovulation in goldfish. Gen. Comp. Endocrinol. 67, 301-307.

Kobayashi, M., Aida, K., and Hanyu, I. (1989). Involvement of steroid hormones in the preovulatory gonadotropin surge in female goldfish. Fish Physiol. Biochem. 7, 141-146.

Lamba, V. J., Goswami, S. V. and Sundararaj, B. I. (1982). Radioimmunoassay for plasma cortisol, testosterone, estradiol-17 $\beta$ and estrone in catfish, Heteropneustes fossilis (Bloch): Development and validation. Gen. Comp. Endocrinol. 47, 170181.

Langeron (1942). Précis de microscopie techniqueexpérimentation-diagnostic. Masson et Cie, Paris.

Matsuyama, M., Adachi, S., Nagahama, Y., Kitajima, 
C., and Matsura, S. (1991). Annual reproductive cycle of the captive female Japanese sardine Sardinops melanostictus: Relationship to ovarian development and serum levels of gonadal steroid hormones. Mar. Biol. 108, 21-29.

Nagahama, Y. (1987). 17 $\alpha, 20 \beta$-dihydroxy-4-pregnen3-one: A teleost maturation-inducing hormone. Devel. Growth Differ. 29, 1-12.

Nagahama, Y., and Yamoshita, M. (1989). Mechanisms of synthesis and action of $17 \alpha, 20 \beta-$ dihydroxy-4-pregnen-3-one, a teleost maturationinducing substance. Fish Physiol. Biochem. 7, 193-200.

Nagler, J. J., and Idler, D. R. (1992). In vitro ovarian estradiol-17 $\beta$ and testosterone responses to pituitary extract and corresponding serum levels during the prespawning to vitellogenic phases of the reproductive cycle in winter flounder (Pseudopleuronectes americanus). Comp. Biochem. Physiol. A 101, 69-75.

Pankhurst, N. W., and Conroy, A. M. (1987). Seasonal changes in reproductive condition and plasma levels of sex steroids in the blue cod, Parapercis colias (Bloch and Schneider) (Mugiloididae). Fish Physiol. Biochem. 4, 15-26.

Pankhurst, N. W., and Conroy, J. F. (1988). Endocrine changes during gonadal maturation and spawning in the orange roughy (Hoplostethus atlanticus Collett), a teleost from midslope waters off New Zealand. Gen. Comp. Endocrinol. 70, 262-273.

Penaz, M., and Proke, M. (1978). Reproduction and early development of the gudgeon Gobio gobio. 1. Spawning and embryonic period. Folia Zool. 27(3), 257-267.

Prat, F., Zanuy, S., Carrillo, M., De Mones, A., and Fostier, A. (1990). Seasonal changes in the plasma levels of gonadal steroids of sea bass Dicentrarchus labrax L. Gen. Comp. Endocrinol. 78, 361373.

Rosenblum, P. M., Pudney, J., and Callard, I. P. (1987). Gonadal morphology, enzyme histochemistry and plasma steroid levels during the annual reproductive cycle of male and female brown bullhead catfish. Ictalurus nebulosus Lesueur. J. Fish Biol. 31, 325-341.

Scott, A. P., Bye, V. J., and Baynes, S. M. (1980). Seasonal variations in sex steroids of female rainbow trout (Salmo gairdneri Richardson). J. Fish Biol. 17, 587-592.

Scott, A. P., Sumpter, J. P., and Hardiman, P. A. (1983). Hormone changes during ovulation in the rainbow trout (Salmo gairdneri Richardson). Gen. Comp. Endocrinol. 49, 128-134.

Scott, A. P., and Sumpter, J. P. (1983). A comparison of the female reproductive cycles of autumn spawning and winter spawning strains of rainbow trout, Salmo gairdneri. Gen. Comp. Endocrinol. $52,79-85$.

Tamaru, C. S., Kelley, C. D., Lee, C.-S., Aida, K., Hanyu, I., and Goetz, F. (1991). Steroid profiles during maturation and induced spawning of the striped mullet, Mugil cephalus L. Aquaculture 95, 149-168.

Young, G., Crim, L. W., Kagawa, H., Kambegawa,

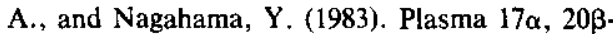
dihydroxy-4-pregnen-3-one levels during sexual maturation of amago salmon (Oncorhynchus rhodurus): Correlation with plasma gonadotropin and in vitro production by ovarian follicles. Gen. Comp. Endocrinol. 51, 96-105.

Wallace, R. A., and Selman, K. (1981). Cellular and dynamic aspects of oocyte growth in teleosts. Am. Zool. 21, 325-343. 